\title{
Sobre La intérprete
}

About La intérprete 
La conformación de una poética - y una metapoética - que definan la obra de un autor a través del tiempo implica tener en cuenta los cambios ocurridos en los enfoques temáticos predominantes, según los momentos de su producción. En el caso de Mayorga, que en sus primeras obras mostraba un claro predominio de la memoria como eje vertebral de su dramaturgia, en sus textos más recientes, se puede observar un desplazamiento hacia las formas metateatrales, una clara intención de asumir la misión del teatro mediante diversas formas de auto-reflexión, de un permanente volver sobre sí mismo, para presentar una imagen del mundo que abra los ojos del espectador frente a lo que se le oculta. Ya sea a través de la reflexión directa sobre nuestra percepción de la realidad (Intensamente azules, 2018), como de la exposición satírica de las fábulas que construyen lo cotidiano (Famélica, 2016) o por las referencias a la "mágica” posibilidad del teatro de cambiar nuestra forma de ver la "verdad de las cosas" (El mago, 2018), los guiños autorreferenciales se suceden con una recurrencia que los convierten tanto en el recurso como en el tema más utilizado por el autor.

Desde esta perspectiva deberíamos leer La intérprete, texto escrito (y reescrito) por Mayorga en los últimos años, donde la relación entre la traducción (o interpretación) y el teatro abarca muchas aristas de su poética y metapoética. Además de la ambigüedad del juego etimológico que fundamenta los vínculos (interpretar es un término que puede ser utilizado, como en este caso, para referirse a una traducción o a una "forma de entender", pero también puede significar el trabajo de un actor respecto de su personaje) la traducción toma aquí el sentido de reconstrucción de la 
verdad, sujeta a las ideologías, las pasiones y la perspectiva de la intérprete, quien busca, como una utopía, llegar a un lenguaje universal, es decir, quien tiene en su horizonte el mismo horizonte del teatro.

Ese eje se conjuga en el drama con una serie de guińos y/o auto-referencias que complementan la idea vertebral y se relacionan con lo metateatral, entre los más visibles, la filosofía se muestra como el disparador del conflicto dramático de Sonia, que define a su traducción como una "traición”, lo que coloca a la palabra como centro de la lucha interior. Así también el boxeo, desde la idea del enfrentamiento, del agón, que constituye un reflejo de lo dramático. El énfasis en la palabra como forma ilusoria, paradójica e insuficiente de construir el mundo, constituyen aquí tanto una referencia metadramática como una reflexión sobre la temática que busca interrogar en el estricto sentido del término y reclama esa palabra final en el silencio compartido con el espectador.

Ofrecemos aquí un extenso fragmento de La intérprete, obra inédita, gracias a la gentileza de Juan Mayorga y la Editorial $u \tilde{N} a$ RoTa, de Madrid. Se trata de cuatro secuencias (3 a 6) de las seis que componen la obra. La primera secuencia presenta el conflicto de Sonia, atormentada por la conferencia de un filósofo, que acaba de traducir, con la culpa de haber cambiado el final. En la segunda, se inicia - con Marcos, su viejo maestro - el recorrido de la protagonista por sucesivos encuentros, de los que dan cuenta las siguientes secuencias de la obra que, a continuación, presentamos. 
